\title{
Rice Cultivation and Greenhouse Gas Fluxes: Monitoring, Quantification, Adaptation and Mitigation
}

ISSN: 2637-7659

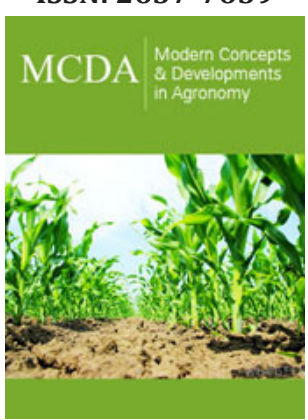

*Corresponding author: Suvadip Neogi, Global Centre for Environment and Energy, Ahmedabad University, Ahmedabad, Gujarat, India

Submission: 悳 December 11, 2019

Published: 㳑January 24, 2020

Volume 5 - Issue 4

How to cite this article: S Neogi, PK Dash, SR Padhy, P Bhattacharyya. Rice Cultivation and Greenhouse Gas Fluxes: Monitoring, Quantification, Adaptation and Mitigation. Mod Concep Dev Agrono.5(4). MCDA.000620.2020.

DOI: 10.31031/MCDA.2020.05.000620

Copyright@ Suvadip Neogi This article is distributed under the terms of the Creative Commons Attribution 4.0 International License, which permits unrestricted use and redistribution provided that the original author and source are credited.

\author{
S Neogi' ${ }^{1 *}$, PK Dash ${ }^{2}$, SR Padhy ${ }^{2}$ and P Bhattacharyya ${ }^{2}$ \\ ${ }^{1}$ Global Centre for Environment and Energy, Ahmedabad University, Ahmedabad, Gujarat, \\ India
}

${ }^{2}$ Crop Production Division, ICAR-National Rice Research Institute, Cuttack, Odisha, India

\begin{abstract}
Rice is grown in different environments ranging from tropical to temperate regions with varying climatic, edaphic, and biological conditions and agricultural management. Tropical and subtropical lowland rainfed rice is usually grown in bunded fields that are flooded with rainwater for at least part of the cropping season. On the other hand, medium upland or upland rice productions are practiced by managed irrigation applications or may be somewhat rainfed. Large amounts of water are generally used in rice production and a significant portion of the total water requirement is used for land preparation which is unique. Rice cultivation acts as an anthropogenic manipulator of ecosystem carbon (C) and nitrogen (N) dynamics through uptake, fixation, emission and transfer of $\mathrm{C}$ and $\mathrm{N}$ between biospheric, lithospheric and atmospheric pools. Rice cultivation has a potential role in the global budget of potent greenhouse gases (GHGs) such as methane $\left(\mathrm{CH}_{4}\right)$, carbon dioxide $\left(\mathrm{CO}_{2}\right)$, and nitrous oxide $\left(\mathrm{N}_{2} \mathrm{O}\right)$. But large variability exists in $\mathrm{CO}_{2}, \mathrm{CH}_{4}$ and $\mathrm{N}_{2} \mathrm{O}$ fluxes in both spatio-temporal scales and their relative contribution changes with management practices. Therefore, field level studies for seasonal, annual and inter-annual scales are indeed needed for precise quantification of GHGs exchanges employing state-of-the art sampling and measurement technology. Hence, from the environmental sustainability point of view, the agricultural management practices for rice production should so improvised by adopting mitigation cum adaptation approaches that these could help in abatement of GHGs emission to atmosphere.
\end{abstract}

Keywords: Rice; Greenhouse gas emission; Monitoring; Quantification; Mitigation; Adaptation

\section{Introduction}

Rice is the major food crop in Asia. About $80 \%$ of it is grown under flooded conditions [1]. In 2010, approximately 154 million ha were harvested worldwide, of which 137 million ha (88 percent of the global rice harvested) were in Asia, of which 48 million ha (31 percent of the global rice harvested) were harvested in Southeast Asia alone [2]. Rice is grown in different environments ranging from tropical to temperate regions with varying climatic, edaphic and biological conditions and under different agricultural management practices which naturally affect the rates of potent agriculturally important GHGs namely $\mathrm{CH}_{4}, \mathrm{CO}_{2}$ and $\mathrm{N}_{2} \mathrm{O}$ emissions fluxes $[3,4]$. Carbon dioxide is the most important anthropogenic GHG. During rice cultivation $\mathrm{CO}_{2}$ originates from burning of fossil fuels due to operation of farm machinery while soil tillage for land preparation, microbial decomposition of soil organic carbon and matter (SOC and SOM) and soil-crop respiration [5,6]. Soil $\mathrm{CO}_{2}$ efflux is usually measured with the help of soil respiration chamber or sampling is done by manual closed / automatic chamber from soil-crop system and quantified using gas chromatography $[7,8]$. The state of the art eddy covariance (EC) technique is also employed for quantifying ecosystem level net ecosystem $\mathrm{CO}_{2}$ exchange (NEE) [5].

On the other hand, flooding of irrigated rice fields produces anaerobic soil conditions which are conducive to the production of $\mathrm{CH}_{4}$ due to the action of methanogenic bacteria $[4,9]$. Methane emission from rice cultivation is usually measured by manual closed / automatic chamber method using gas chromatography or by micrometeorological method like EC technique which measures net ecosystem methane exchange (NEME) [3-5]. Nitrous oxide 
is generated by the microbial transformation of $\mathrm{N}$ in rice soils and manures. It is often found to be enhanced where available $\mathrm{N}$ exceeds plant requirements, especially under wet conditions as found in rice cultivation [10]. The rice paddies act as sources of major $\mathrm{N}_{2} \mathrm{O}$ emission upon nitrogenous fertilizer (e.g. urea) application. Nitrous oxide is usually measured by manual closed / automatic chamber method using gas chromatography $[7,8]$ or by micrometeorological method (EC technique), but its application is limited due to very expensive trace gas analyzer and the technologies involved [11]. Many of the factors controlling exchanges of GHGs fluxes between rice paddies and the atmosphere are different from any other agricultural practices and ecosystems because rice is flooded during most of its cultivation period [12].

Moreover, GHGs fluxes in terms of gaseous $\mathrm{C}$ and $\mathrm{N}$ between rice fields and the atmosphere are controlled by several biological and physical processes. The GHGs flux dynamics during rice cultivation follows complex pathways and shows variability at different time scales [5,13]. Therefore, field-cum-laboratory-based studies to measure gaseous $\mathrm{C}\left(\mathrm{CO}_{2}+\mathrm{CH}_{4}\right)$ and $\mathrm{N}\left(\mathrm{N}_{2} \mathrm{O}\right)$ fluxes from soilcrop system and to improve the understanding of the associated factors mitigating the GHGs fluxes are important. The continuous monitoring and measurement provide a useful understanding for examining the roles of different rice and rice based production systems contributing to GHGs fluxes under different agro-climatic zones and management practices [14]. The study could also be employed to explore better understanding of GHGs exchanges for scaling up gaseous $\mathrm{C}$ and $\mathrm{N}$ fluxes from point scale to and it could further be upscaled for predicting future anticipated climate change [15]. An array of factors like range of soil, climatic variables, physicochemical-biological interactions in crop-soil and agricultural management practices influence the production and subsequent emission of gaseous $\mathrm{C}$ and $\mathrm{N}$ from rice and rice-based production systems $[16,17]$. Hence, by manipulating soil temperature, soil moisture, $\mathrm{pH}, \mathrm{SOM}$, organic manure and fertilizer applications, water management, cultivar selection, tillage practices etc. (in totality crop-soil management and agronomic practices), either singly or in optimized combination, and by adopting judicious land use management practices, GHGs emission could be mitigated.

\section{Sampling, monitoring techniques and estimation of greenhouse gas fluxes from rice and rice-based production systems}

$\mathrm{CO}_{2}, \mathrm{CH}_{4}$ and $\mathrm{N}_{2} \mathrm{O}$ flux monitoring and quantification from crop-soil system using manual closed / automatic chambers: Greenhouse gas (viz. $\mathrm{CO}_{2}, \mathrm{CH}_{4}$ and $\mathrm{N}_{2}$ ) fluxes from the soil-crop system of rice fields are monitored by manual closed chamber method or automatic chamber method. Sampling for GHGs flux measurements are done from replicated plots in the morning (9:00-9:30h) and afternoon (15:00-15:30h) and the average of the morning and afternoon fluxes are used as the flux for the day. The gas samplings are performed soon after sowing / transplanting of the rice at close intervals throughout the cropping season. This may also be applied on bare soil in fallow periods or in rice nurseries. The sampling days generally encompass beginning from early growth stage of the crop through vegetative, reproductive phase till physiological maturity of the crop. For sampling and estimation of GHGs fluxes, generally six rice hills are covered with a Perspex chamber $(53 \mathrm{~cm} \times 37 \mathrm{~cm} \times 51 \mathrm{~cm}$; length $\times$ width $\times$ height from seedling to tillering stage and $53 \mathrm{~cm} \times 37 \mathrm{~cm} \times 71 \mathrm{~cm}$; length $\times$ width $\times$ height from maximum tillering to maturity stage) and placed on aluminum base plate inserted into the soil (Figure 1) [3,4,7,8,18,19].

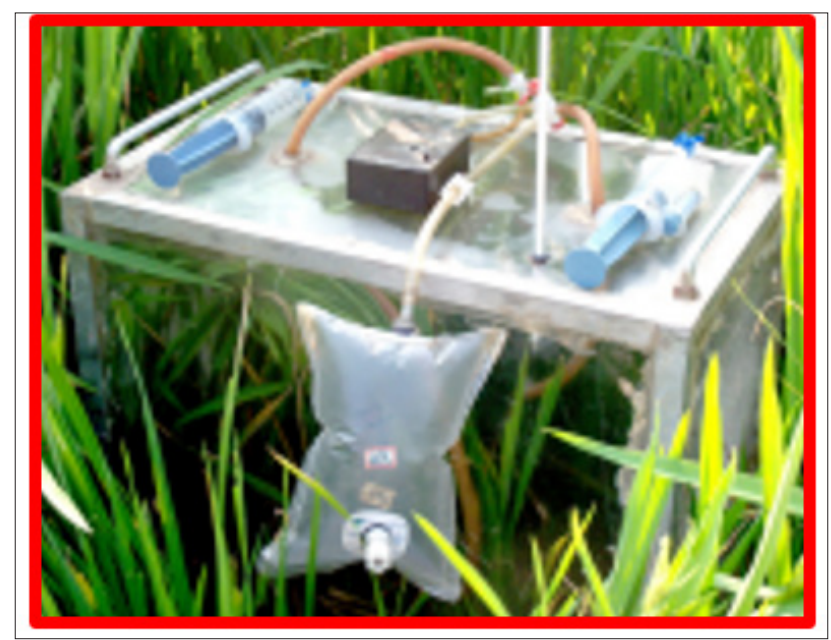

Figure 1: Closed chamber and accessories for collection of GHGs (source: adapted from [21]).

A battery operated air circulation pump with an air displacement of $\sim 1.5 \mathrm{~L} \mathrm{~min}^{-1}$ and connected to polyethylene tubing is used to mix air inside the chamber and draws the air samples into gas sampling bags (tedlar bags) at fixed intervals of 0,15 and $30 \mathrm{~min}$. Gas samples from the sampling bags are analyzed for $\mathrm{CO}_{2}, \mathrm{~N}_{2} \mathrm{O}$ and $\mathrm{CH}_{4}$ concentrations to determine respective fluxes employing gas chromatograph fitted with thermal conductivity detector (TCD) (or in sometimes using methanizer along with flame ionization detector, FID), electron capture detector (ECD) and FID, respectively. Cumulative GHGs fluxes and emission for the entire cropping period are computed by plotting the flux values against the days of sampling and is expressed in unit $\mathrm{kg} \mathrm{ha}^{-1}$. These chamber 
measurements are widely used as they are easy to apply in multiple small plots in fields. The automatic chamber measurements allow continuous and frequent measurements of GHGs fluxes and are expected to produce more reliable results compared to manual chamber measurements as diurnal variations of GHGs fluxes are duly taken care of. But, the automatic chamber measurements suffer from underestimation of fluxes due to chamber effects on soil moisture conditions during rainfall or pressure-temperature variations, which are corrected afterwards during post-processing of data $[20,21]$.
Use of soil respiration chamber: Soil $\mathrm{CO}_{2}$ fluxes are analyzed by environmental gas monitor chamber equipped with infrared gas analyzer and attached to a data logger. A flag or marker is placed at the exact spot in the plot from where a $\mathrm{CO}_{2}$ flux is measured throughout the study period. The soil respiration chamber is placed on the soil surface for $2 \mathrm{~min}$ in each spot until $\mathrm{CO}_{2}$ flux measurements are recorded in data logger (Figure 2). The $\mathrm{CO}_{2}$ flux is recorded from the inter-row position of the rice plants. All measurements are recorded at 9:00-12:00h and 15:00-17:00h [6]. The average of the morning and afternoon fluxes are considered as daily flux and cumulative $\mathrm{CO}_{2}$ emissions are expressed as $\mathrm{kg} \mathrm{ha}^{-1}$.

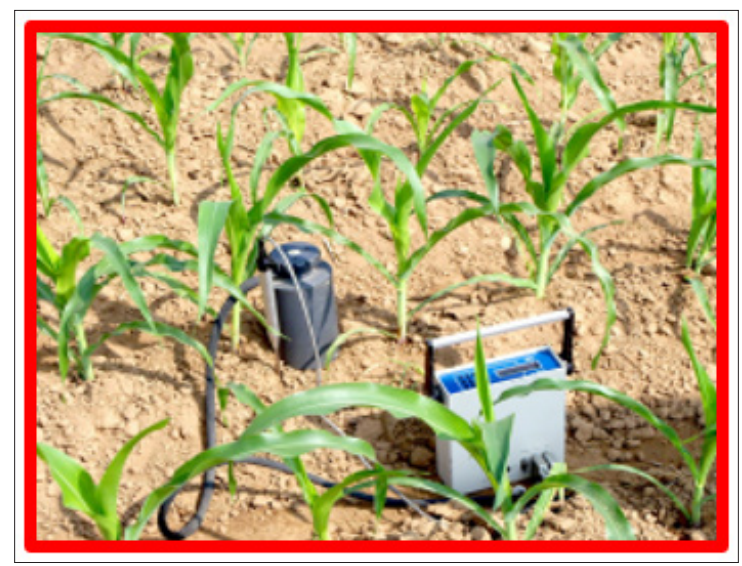

Figure 2: Soil respiration chamber (source: adapted from [21]).

Use of chamber connected to automatic $\mathrm{CH}_{4}$ analyzer: For application of standard direct method of $\mathrm{CH}_{4}$ flux analysis, a portable chamber is used to estimate the methane emissions from the paddy fields of the study site (Figure 3). The chamber is made with Perspex with an exhaust fan fitted at one of the sides. The fan operates for about $5 \mathrm{~min}$ just before sampling, in order to ensure homogeneous mixing of gases within the chamber. The suction pipe of the methane analyser is fitted into the ceiling of the hood. The Perspex chamber is used on a channel inserted into the soil prior to transplantation. During the analysis, the channel is filled with water to make it leak tight. The analysis is done on field using a methane analyser equipped with FID [22,23].

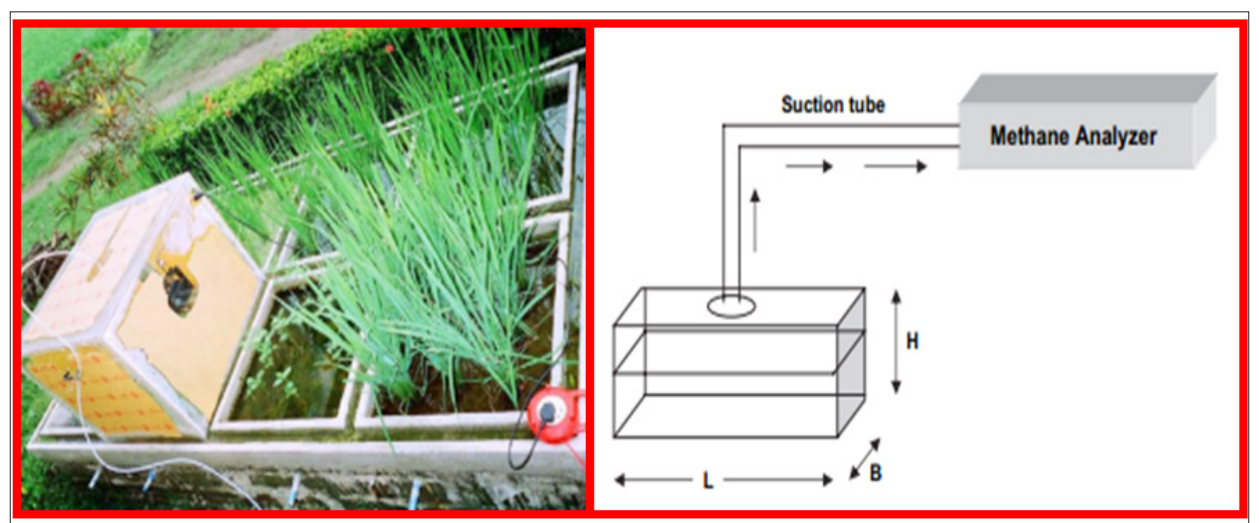

Figure 3: The portable hood and chamber for measurement of methane flux (source: adapted from [23]).

$\mathrm{CO}_{2}, \mathrm{CH}_{4}$ and $\mathrm{N}_{2} \mathrm{O}$ flux monitoring and quantification from crop-soil system using micrometeorological approach: Apart from manual closed / automatic chamber method, employing micrometeorological eddy covariance (EC) technique based continuous real time monitoring of net ecosystem $\mathrm{CO}_{2}$ (net ecosystem carbon dioxide exchange, $\mathrm{NEE}$ ) $\mathrm{CH}_{4}$ (net ecosystem methane exchange, NEME) exchanges are also possible $[3,5,24]$ (Figure 4). This EC technique can measure vertical turbulent flux of $\mathrm{CO}_{2}$ and $\mathrm{CH}_{4}$ in the atmospheric boundary layer. This technique provides a direct measure of the turbulent flux of a scalar (here GHG of interest) across upwind. The EC method can be used for continuous in-situ measurements over the large area causing no 
disturbance to the vegetation over which fluxes are measured. The EC technique is based on high frequency $(10-20 \mathrm{~Hz})$ measurements of wind speed and wind direction as well as $\mathrm{CO}_{2}$ and $\mathrm{CH}_{4}$ concentrations at a point over the canopy using a three-axis sonic anemometer and a fast response infrared gas analyzer. The two sensors, three-axis sonic anemometer and fast response infrared gas analyzer/methane analyzer, are normally installed at $1.5-3 \mathrm{~m}$ height (depends on the rice canopy).

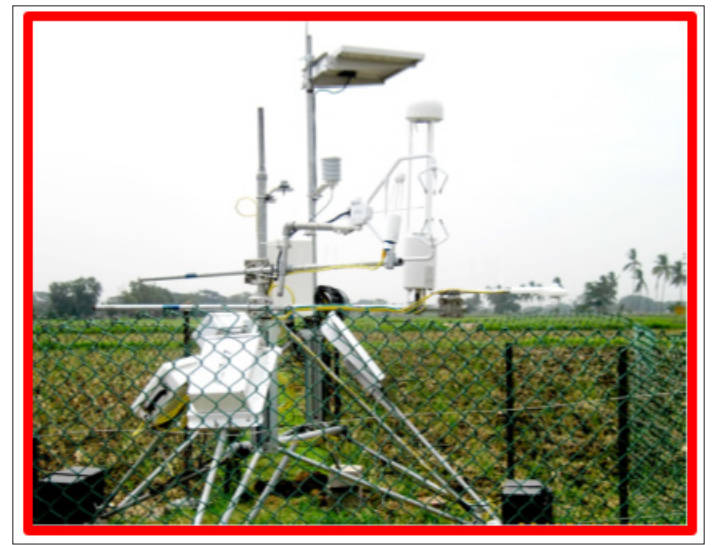

Figure 4: Open path eddy covariance system installed in rice field (source: adapted from [21]).

The mean vertical flux density of $\mathrm{CO}_{2}$ or $\mathrm{CH}_{4}$ is obtained as the 30minute covariance between vertical fluctuations of air density and the $\mathrm{CO}_{2}$ or $\mathrm{CH}_{4}$ mixing ratio. A positive covariance indicates net GHG $\left(\mathrm{CO}_{2}\right.$ or $\left.\mathrm{CH}_{4}\right)$ transfer into atmosphere and a negative value indicates net $\mathrm{GHG}$ absorption by the vegetation $\left(\mathrm{CO}_{2}\right) /$ soil $\left(\mathrm{CH}_{4}\right)$. The NEE is further partitioned into gross primary production (GPP) and ecosystem respiration (RE). An eddy covariance system integrated with trace gas analyzer (TGA), a tunable diode laser analyzer, can measure trace gas fluxes viz. $\mathrm{N}_{2} \mathrm{O}$. Eddy covariance measurements of $\mathrm{N}_{2} \mathrm{O}$ using lead salt tunable diode laser (TDL) spectrometers and quantum cascade laser (QCL) spectrometers are being also practiced, but due to high cost involved, its application is somewhat limited [11].

\section{Factors for GHGs fluxes and emission quantifications from rice and rice-based production systems}

The atmospheric concentration of $\mathrm{CO}_{2}$ has drastically increased from 280 parts per million by volume (ppmv) in 1750 (preindustrial revolution) to $402 \mathrm{ppmv}$ in present day [25] and is currently increasing at the rate of $1.9 \mathrm{ppmv} \mathrm{yr}^{-1}$ [26]. Atmospheric $\mathrm{CH}_{4}$ concentration has increased from about 715 to 1827 parts per billion by volume (ppbv) at present [27] over the same period and is increasing at the rate of $7 \mathrm{ppbv} \mathrm{yr}^{-1}$ [26]. Similarly, the atmospheric concentration of $\mathrm{N}_{2} \mathrm{O}$ has increased from about $270 \mathrm{ppbv}$ in 1750 to $325 \mathrm{ppbv}$ at present [27] and is increasing at

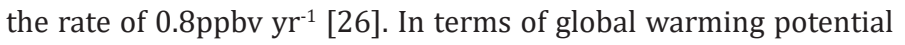
(GWP) amongst these three GHGs for a period of 100-year time horizon the order is like $\mathrm{N}_{2} \mathrm{O}>\mathrm{CH}_{4}>\mathrm{CO}_{2}$ [26]. Agriculture accounted

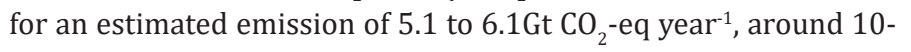
$12 \%$ of total global anthropogenic emissions of GHGs, where $\mathrm{CH}_{4}$ contributed 3.3Gt $\mathrm{CO}_{2}$-eq year-1 and $\mathrm{N}_{2} \mathrm{O} 2.8 \mathrm{Gt}^{\mathrm{CO}_{2} \text {-eq year-1 }}$ [26]. Of global anthropogenic GHG emissions, agriculture accounted for about $60 \%$ of $\mathrm{N}_{2} \mathrm{O}$ and $50 \%$ of $\mathrm{CH}_{4}[26]$.

\section{Factors for $\mathrm{CO}_{2}$ fluxes and emission quantifications}

There are several factors influencing $\mathrm{CO}_{2}$ production and emission from the soil. These include soil texture, moisture, $\mathrm{pH}$ and salinity which influence $\mathrm{CO}_{2}$ production through their effect on soil microbial activity and root respiration. Apart from these, external factors viz. tillage, irrigation, temperature, fertilizer and manure application also have an effect on $\mathrm{CO}_{2}$ production and emission [28]. During rice cultivation tillage practices, SOM decompositions and soil-crop respirations (heterotrophic + autotrophic) are mainly responsible for $\mathrm{CO}_{2}$ emission to the atmosphere. But in case of lowland flooded rice ecology the total $\mathrm{CO}_{2}$ emissions due to respirations are often found to be nullified by the gross primary production (photosynthesis) and the resultant net $\mathrm{CO}_{2}$ flux remains negative (negative NEE) representing the ecosystem as net $\mathrm{CO}_{2}-\mathrm{C}$ sink [5,29]. Different scenario is experienced in upland aerobic rice production [30].

During crop season (heading to maturity stage; chemical fertilization and drained soil condition), daily NEE $\left(\mathrm{CO}_{2}\right.$ flux $)$ in rice in Taiwan varied from -17.0 to $12.9 \mu \mathrm{mol} \mathrm{CO}_{2} \mathrm{~m}^{-2} \mathrm{~s}^{-1}$.

The NEE was positive during night, average value $\sim 2.8 \mu \mathrm{mol}$ $\mathrm{CO}_{2} \mathrm{~m}^{-2} \mathrm{~s}^{-1}$; whereas during the daytime the flux was negative, average value $\sim-1.2 \mu \mathrm{mol} \mathrm{CO}_{2} \mathrm{~m}^{-2} \mathrm{~s}^{-1}$ [9]. The NEE exhibited a clear diurnal pattern varying between -38 to $10 \mu \mathrm{mol} \mathrm{CO}_{2} \mathrm{~m}^{-2} \mathrm{~s}^{-1}$ during full heading stage of rice in Bangladesh (chemical fertilization and flooded soil condition) [31]. In rice fields in Japan, NEE varied between -16.9 to $9.3 \mu \mathrm{mol} \mathrm{CO}_{2} \mathrm{~m}^{-2} \mathrm{~s}^{-1}$ (chemical fertilization and drained soil condition; 1 month before heading stage) and -19.6 to $4.3 \mu \mathrm{mol} \mathrm{CO} \mathrm{m}^{-2} \mathrm{~s}^{-1}$ (chemical fertilization and flooded soil condition; 1 month before heading stage) due to different management practices [32]. Seasonal integrated NEE varied from $-258 \mathrm{~g} \mathrm{Cm}^{-2}$ (flooded rice fields) to $-85 \mathrm{~g} \mathrm{Cm}^{-2}$ (aerobic rice fields) in IRRI, 
Philippines [29]. In lowland submerged rice ecology in Eastern India the seasonal integrated $\mathrm{NEE}$ was $\sim-448 \mathrm{~g} \mathrm{Cm}^{-2}$ [3].

Annual average soil respiration rates and total soil respiration of paddy soil in the subtropical region of China were estimated to be $178.5-259.9 \mathrm{mg} \mathrm{m}^{-2} \mathrm{~h}^{-1}$ and $1.56-2.28 \mathrm{~kg} \mathrm{~m}^{-2} \mathrm{yr}^{-1}$, respectively. The soil respiration rates at night times during the fallow periods (in absence of rice crops) were 52-398mg $\mathrm{m}^{-2} \mathrm{~h}^{-1}$ [33]. Introduction of minimum tillage (MT) in rice-based production systems led to significantly reduce $\mathrm{CO}_{2}$ emission from soil. The $\mathrm{CO}_{2}-\mathrm{C}$ emissions, as a whole, were $24 \%$ higher in between plants than in rows, and were in the range of 23.4-78.1, 37.1-128.1, and 28.6-101.2mg m-2 $\mathrm{h}^{-1}$ under conventional tillage (CT) and 10.7-60.3, 17.3-99.1, and 17.2$79.1 \mathrm{mg} \mathrm{m}^{-2} \mathrm{~h}^{-1}$ under MT in rice, maize, and cowpea, respectively. The $\mathrm{CO}_{2}$-C emission was found highest under maize (44\%) followed by rice (33\%) and cowpea (23\%) irrespective of CT and MT practices [6]. Combined application of rice straw (RS) and green manuring (GM) showed higher seasonal $\mathrm{CO}_{2}$-C flux $\left(\sim 1858 \mathrm{~kg} \mathrm{ha}^{-1}\right)$ than control $\left(\sim 1100 \mathrm{~kg} \mathrm{ha}^{-1}\right)$ in lowland submerged rice. But due to higher grain yield, the emission per unit yield was significantly lower [8].

\section{Factors for $\mathrm{CH}_{4}$ fluxes and emission quantifications}

Methane is released to the atmosphere by ebullition, diffusion across floodwater-air interface and by transport through aerenchyma $[3,4,7,8]$. In undisturbed paddy fields $\sim 90 \%$ of $\mathrm{CH}_{4}$ emission occurs through aerenchyma [34]. Flooded rice soils are favorable for the production and emission of $\mathrm{CH}_{4}$ due to methanogenic bacteria which utilize readily decomposable organic compounds under anaerobic soil condition [3,4]. Both $\mathrm{CH}_{4}$ production and emission from flooded rice soils are strongly driven by several soil processes namely changes in soil redox status and $\mathrm{pH}$, dynamics of substrate and nutrient availability etc. [35] Besides, $\mathrm{CH}_{4}$ emission is also influenced by cultivation practices and agricultural management viz. chemical fertilizer and agrochemicals application, organic matter amendment etc.

The net emission from an agricultural system is the result of production (methanogenesis) and consumption (methanotrophy). Whether the net emission is positive or negative depends on the relative magnitudes of these processes. However, $\mathrm{CH}_{4}$ production in rice fields depends on soil characteristics (organic carbon, $\mathrm{OC}$ ), rice varieties (especially morphology and physiology), management practices (fertilizer application, water management, land preparations). Continuous flooding, pure mineral fertilizer, organic manure amendments, root exudates, and cultivar types have found to influence on $\mathrm{CH}_{4}$ emission [36]. Methane emissions exhibit large spatio-temporal variations. Among the sources of $\mathrm{CH}_{4}$, irrigated rice fields are estimated to contribute between $6-8 \%$ of the total 410 660 million tons $\mathrm{yr}^{-1}$ emitted globally [9]. Methane emission varied from 14 to $375 \mathrm{mg} \mathrm{m}^{-2} \mathrm{~d}^{-1}$ in most rice growing areas in the world [37].

Annual global estimation of $\mathrm{CH}_{4}$ emission from flooded rice fields was accounted for 7.08Tg [38]. In Thailand $\mathrm{CH}_{4}$ emission was estimated $\sim 99 \mathrm{~kg} \mathrm{CH}_{4}$ ha $^{-1}$ season $^{-1}$ from deep water rice fields [39].
Average $\mathrm{CH}_{4}$ emission rates ranged between $11-364 \mathrm{mg} \mathrm{m}^{-2} \mathrm{~d}^{-1}$ in rice fields of Beijing, China [40]. In India the mean $\mathrm{CH}_{4}$ emission

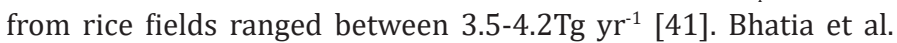
[42] estimated 4.7 $\mathrm{Tg} \mathrm{yr}^{-1} \mathrm{CH}_{4}$ emission from the Indian paddy fields with the highest emission of $1.379{\mathrm{Tg} \mathrm{yr}^{-1}}^{-}$from the irrigated rice fields. For the first time in India, employing EC system in lowland submerged rice ecology Bhattacharyya et al. [5] quantified NEME $\sim 84$ and $129 \mathrm{~kg} \mathrm{ha}^{-1}$ in two consecutive rice growing seasons and the annual NEME was $\sim 262 \mathrm{~kg} \mathrm{ha}^{-1}$. Alberto et al. [43] estimated seasonal $\mathrm{CH}_{4}$ emission in irrigated rice fields of IRRI and it has been found that the ecosystem released $3.03 \mathrm{~g} \mathrm{Cm}^{-2}$ of $\mathrm{CH}_{4}-\mathrm{C}$ to the atmosphere during the growing period.

\section{Factors for $\mathrm{N}_{2} \mathrm{O}$ fluxes and emission quantifications}

Nitrous oxide is a byproduct of denitrification and nitrification processes in soil. Nitrification is the main source of $\mathrm{N}_{2} \mathrm{O}$ production followed by emission under aerobic conditions, while denitrification dominates under flooded rice fields $[7,8]$. Nitrification is the process of oxidation of ammonium form of $\mathrm{N}$ to nitrite or nitrate form and subsequent emission of $\mathrm{N}_{2} \mathrm{O}$ from soil. On the other hand, denitrification is the microbial reduction of nitrate or nitrite form of $\mathrm{N}$ to dinitrogen or oxides of $\mathrm{N}$ under anaerobic condition $[3,4]$. Several microbiological and ecological factors influence $\mathrm{N}$ transformation processes in soil and hence $\mathrm{N}_{2} \mathrm{O}$ production-emission. Nitrous oxide is primarily emitted in pulses after fertilization and strong rainfall events. Land use practices and $\mathrm{N}$ fertilizer applications greatly influence $\mathrm{N}_{2} \mathrm{O}$ emission from soil.

Type and dose of nitrogenous fertilizer controls the amount of $\mathrm{N}$ flows through the system and hence influences the $\mathrm{N}_{2} \mathrm{O}$ emission [44]. Increase in total $\mathrm{N}_{2} \mathrm{O}$ emission with the increase in $\mathrm{N}$ application rates is one of the responsible factors [45]. In general, soil water content, water filled pore spaces, relative abundance of electron donors (soil organic carbon) and acceptors (primarily oxygen, nitrate, and sulfate), degradable organic matter, soil texture, $\mathrm{pH}$ and salinity regulate $\mathrm{N}_{2} \mathrm{O}$ emission from soil [46]. Chao et al. [47] estimated around $0.67 \mathrm{Mg} \mathrm{N}_{2} \mathrm{O}-\mathrm{N} \mathrm{yr}^{-1}$ from the paddy fields of Taiwan. Nitrous oxide emission from the Chinese rice fields ranged between 39-164mg N m${ }^{-2} h^{-1}$ [48]. Sharma et al. [49] estimated $\mathrm{N}_{2} \mathrm{O}$ emissions from irrigated and upland paddy fields of India $\sim 4-210$ and 2-10Gg $\mathrm{yr}^{-1}$, respectively. Bronson et al. [50] observed $\mathrm{N}_{2} \mathrm{O}$ fluxes in an irrigated rice system were generally negligible during the growing seasons, but small peaks $\left(\sim 3.5 \mathrm{mg} \mathrm{N}_{2} \mathrm{O}-\mathrm{N} \mathrm{m}^{-2} \mathrm{~d}^{-1}\right)$ appeared after $\mathrm{N}$ fertilizer applications.

The $\mathrm{N}_{2} \mathrm{O}$ flux increased sharply during the drainage period. Higher $\mathrm{N}_{2} \mathrm{O}$ flux $\left(\sim 80 \mathrm{mg} \mathrm{N}_{2} \mathrm{O}-\mathrm{N} \mathrm{m}^{-2} \mathrm{~d}^{-1}\right)$ found during fallow period was due to nitrification of mineralized organic $\mathrm{N}$ in the topsoil and possibly from denitrification in the wet subsoil [51]. Kumar et al. [45] observed total $\mathrm{N}_{2} \mathrm{O}-\mathrm{N}$ emissions during crop growth season in an irrigated rice system ranged $\sim 235 \mathrm{~g} \mathrm{~N}_{2} \mathrm{O}-\mathrm{N}^{-1}$ with application of ammonium sulphate and $\sim 160 \mathrm{~g} \mathrm{~N}_{2} \mathrm{O}-\mathrm{N}^{-1}$ with urea application. Worldwide at differently managed rice ecologies (in terms of ecology, irrigation applications and varying $\mathrm{N}$ fertilizer doses) broadly the total seasonal $\mathrm{N}_{2} \mathrm{O}$ emission varied from $\sim 0.15$ to $\sim 0.61 \mathrm{~g} \mathrm{~m}^{-2}[52,53]$. 


\section{Mitigation cum adaptation strategies for reducing gaseous $\mathrm{C}$ and $\mathrm{N}$ emissions from rice and rice-based production systems}

Mitigation cum adaptation strategies for reducing $\mathrm{CO}_{2}$ emissions from rice and rice-based production systems: Carbon dioxide emission depends on the soil-water management, cultivation methods and agricultural operations [54]. Overlying floodwater and its prolonged existence of on rice soil creates anaerobic environment. This helps in slow decomposition of SOM. Moreover, it acts as a diffusion barrier to liberated $\mathrm{CO}_{2}$ from soil to the atmosphere, thereby storing more $C$ in soil $[3-5,29,30,43]$. That's why the aerobic rice cultivation system in upland condition is responsible for higher $\mathrm{CO}_{2}$ emissions as compared to lowland flooded rice soils. No tillage or minimum tillage practices reduce $\mathrm{CO}_{2}$ efflux from soil to the atmosphere rather than conventional tillage and foster more $C$ sequestration in soil [6]. Mulching effect on soil surfaces reduces $\mathrm{CO}_{2}$ emissions from soils, retains soil moisture and, thereby, helps to sequester more $\mathrm{C}$ in soils [55]. Overall, Soil management practices like increasing SOC content, reduced / conservation tillage, manuring, residue incorporation, improving soil biodiversity, micro-aggregation and mulching can play an important role in sequestering C in soil [28].

Mitigation cum adaptation strategies for reducing $\mathbf{C H}_{4}$ emissions from rice and rice-based production systems: Rice cultivation is often regarded as culprits for $\mathrm{CH}_{4}$ production and emission [56]. Mitigation cum adaptation strategies for reducing CH4 emissions from rice and rice-based production systems:

(i) judicious water management [57],

(ii) use of situation specific rice cultivars [58],

(iii) efficient fertilizers management [58],

(iv) manipulation of cropping practices [59],

(v) Effective land management [60] etc.

Overall, these options mainly target management of the crop soil and irrigation requirements, varietal choice and agrochemical usage $[3,4,7,8,61,62]$. The higher age of seedlings at the time of transplanting showed significant impact on subsequent $\mathrm{CH}_{4}$ emission [63]. Hence, the proper selection of rice cultivars is a potential adaptation strategy for reduced $\mathrm{CH}_{4}$ emission. Experimentally screened rice cultivars with proven low $\mathrm{CH}_{4}$ emission potential in a specific situation / ecology may be selected. Methane emission rates were found higher in transplanted rice than direct sown rice [64]. Mid-season drainage has been found to substantially reduce $\mathrm{CH}_{4}$ emissions by about $30-50 \%$ as compared to continuous flooding maintained in rice fields during crop cultivation [64]. Intermittent irrigation applications or cycles of alternate wetting and drying (AWD) as occur in rainfed rice situations led to significant reductions in the $\mathrm{CH}_{4}$ emissions from rice fields [65].
Land management in the winter crop season has been found to significantly influence $\mathrm{CH}_{4}$ emission fluxes following flooded rice growing period [66]. Land management practices in the winter crop season also affected temporal variation patterns of $\mathrm{CH}_{4}$ fluxes and soil redox potential (Eh) after flooding. Therefore, water management in the preceding crop season is a crucial factor in influencing $\mathrm{CH}_{4}$ emission from rice fields [67]. The application of sulphate fertilizers is a suitable option to reduce $\mathrm{CH}_{4}$ emissions by increasing alternative electron acceptors in soil. The partial competition of the sulphate-reducing bacteria with methanogens for C substrate plays crucial role in soil [68]. Application of single super phosphate and potassium fertilizer also led to the decreased cumulative seasonal $\mathrm{CH}_{4}$ emissions.

Sulphur contained in the single super phosphate decreased the $\mathrm{CH}_{4}$ emissions. Potassium helps in maintaining higher levels of oxidation status in the topsoil profile and encourages oxidation processes in the rhizosphere zone [69]. The influence of crop physiology (rhizodeposition) on seasonal $\mathrm{CH}_{4}$ emissions is important factor. Reduction of the rates of rhizodeposition, therefore, is beneficial to both yield and reduced $\mathrm{CH}_{4}$ emissions [70]. Rice straw (RS) composted properly resulted in a six-fold reduction in $\mathrm{CH}_{4}$ emission compared with partially composted RS [71]. Dual cropping of Azolla in conjunction with urea considerably reduced $\mathrm{CH}_{4}$ efflux without affecting the rice yields and can be used as a practical adaptation option for minimizing $\mathrm{CH}_{4}$ flux from flooded paddy [72].

Mitigation cum adaptation strategies for reducing $\mathrm{N}_{2} \mathrm{O}$ emissions from rice and rice-based production systems: Direct relation exists between nitrogen use efficiency (NUE) and $\mathrm{N}_{2} \mathrm{O}$ emissions [73]. These strategies for $\mathrm{N}_{2} \mathrm{O}$ emission reduction include matching $\mathrm{N}$ supply with demand, use of slow release fertilizers, urease and nitrification inhibitors, proper forms of fertilizer, appropriate rate, dose and method of application etc. [74]. Application of $\mathrm{N}$ in splits as per the crop requirement is an important strategy to improve NUE, minimization of $\mathrm{N}$ loss and checking $\mathrm{N}_{2} \mathrm{O}$ emission from soil-crop system [75]. Application of customized leaf colour chart (CLCC) depending on the variety and ecology where the crop is grown for checking leaf greenness and use of SPAD meter in this respect is helpful for determining number of splits, doses and application time as per crop requirement [76]. Addition of nitrification inhibitors viz. dicyandiamide along with urea has been instrumental in reducing $\mathrm{N}_{2} \mathrm{O}$ loss [45,77]. Use of neem oil and karanj oil coatings on urea has been found to reduce $\mathrm{N}_{2} \mathrm{O}$ emissions [78]. Drip irrigation system has been found to reduce the $\mathrm{N}_{2} \mathrm{O}$ emissions compared to the furrow irrigation in arid and semi-arid areas [79]. Denitrification related $\mathrm{N}_{2} \mathrm{O}$ losses from urea application in flooded rice ecology are reduced when urea is deep placed compared to surface broadcast [80]. Application of slow/ controlled release fertilizer (e.g., polyolefin-coated ammonium nitrate) has been found to impart 3-7 fold reduction in $\mathrm{N}_{2} \mathrm{O}$ emissions compared to uncoated ammonium sulfate from arable soil [81]. 


\section{Conclusion and Future Road Map}

The impact of GHGs on climatic conditions and the influence of such climatic change on rice productivity is now a reality, although there is a need to assess the extent of such influences. The holistic studies of GHGs emission flux quantification followed by subsequent validation and upscaling from different rice ecologies and approaches adopted towards GHGs emission mitigation are still lacking. Judicious land use and appropriate management practices (viz. adoption of conservation agriculture and introduction of low carbon resource conservation technologies) would help to mitigate the process of GHGs emission. The GHGs emission depends on the soil and water management, cultivation methods and agronomic operations. The options for GHGs emission reduction largely depend upon the situation and component specific factors.

Thus, the optimized mitigation approaches would be so formulated to include management of the crop, soil and irrigation requirements, physico-chemical-biological factors, varietal choice and agrochemicals usage. Hence, the $\mathrm{C}$ and $\mathrm{N}$ biogeochemistry in agricultural ecosystems (crop-soil system) consisting of the holistic interactions of soil temperature, moisture, $\mathrm{pH}$, redox potential, substrate concentration profile, decompositions and transformations driven by ecological drivers viz. climate, crop / vegetation and management practices need to be studied meticulously for formulation-implementation of better mitigation cum adaptation strategies keeping in mind better soil healthquality and sustained crop productivity.

\section{Acknowledgement}

The authors thankfully acknowledge the support received from the ICAR-National Rice Research Institute. Part of the findings is the Ph.D. work of Mr. S. Neogi.

\section{References}

1. Towprayoon S, Smakgahn K, Poonkaew S (2005) Mitigation of methane and nitrous oxide emission from drained irrigated rice fields. Chemosphere 59(11): 1547-1556.

2. www.faostat.fao.org

3. Bhattacharyya P, Neogi S, Roy KS, Dash PK, Tripathi R, et al. (2013) Net ecosystem $\mathrm{CO}_{2}$ exchange and carbon cycling in tropical lowland flooded rice ecosystem. Nutrient Cycling in Agroecosystems 95: 133-144.

4. Bhattacharyya P, Nayak AK, Mohanty S, Tripathi R, Mohammad Shahid, et al. (2013) Greenhouse gas emission in relation to labile soil C N pools and functional microbial diversity as influenced by 39 years long-term fertilizer management in tropical rice. Soil and Tillage Research 129: 93105.

5. Bhattacharyya P, Neogi S, Roy KS, Dash PK, Nayak AK, et al. (2014) Tropical low land rice ecosystem is a net carbon sink. Agriculture Ecosystems and Environment 189(1): 127-135.

6. Neogi S, Bhattacharyya P, Roy KS, Panda BB, Nayak AK, et al. (2014) Soil respiration labile carbon pools and enzyme activities as affected by tillage practices in a tropical rice-maize-cowpea cropping system. Environmental Monitoring and Assessment 186(7): 4223-4236.

7. Bhattacharyya P, Roy KS, Neogi S, Chakravorti SP, Behera KS, et al. (2012) Effect of long term application of organic amendment on C storage in relation to global warming potential and biological activities in tropical flooded soil planted to rice. Nutrient Cycling in Agroecosystems 94: 273285.
8. Bhattacharyya P, Roy KS, Neogi S, Adhya TK, Rao KS, et al. (2012) Effects of rice straw and nitrogen fertilization on greenhouse gas emissions and carbon storage in tropical flooded soil planted with rice. Soil and Tillage Research 124: 119-130.

9. Tseng HK, Tsai LJ, Alagesan A, Tsuang JB, Yao HM, et al. (2010) Determination of methane and carbon dioxide fluxes during the rice maturity period in Taiwan by combining profile and eddy covariance measurements. Agricultural and Forest Meteorology 150(6): 852-859.

10. Oenema O, Wrage N, Velthof GL, van Groenigen JW, Dolfing J, et al. (2005) Trends in global nitrous oxide emissions from animal production systems. Nutrient Cycling in Agroecosystems 72: 51-65.

11. Neftel A, Flechard C, Ammann C, Conen F, Emmenegger L, et al. (2007) Experimental assessment of $\mathrm{N}_{2} \mathrm{O}$ background fluxes in grassland systems. Tellus 59(3): 470-482.

12. Liu Y, Wan K, Tao Y, Li Z, Zhang G (2013) Carbon Dioxide flux from rice paddy soils in Central China: Effects of intermittent flooding and draining cycles. PLoS ONE 8(2): e56562.

13. Wu L, Rees RM, Tarsitanob D, Zhanga X, Jones SK, et al. (2015) Simulation of nitrous oxide emissions at field scale using the SPACSYS model. Science of the Total Environment 530-531: 76-86.

14.Zhang H, Bai X, Xue J, Chen Z, Tang $\mathrm{H}$ (2013) Emissions of $\mathrm{CH}_{4}$ and $\mathrm{N}_{2} \mathrm{O}$ under different tillage systems from double-cropped paddy fields in Southern China. PLoS ONE 8(6): e65277.

15. Pathak H, Li C, Wassmann R (2005) Greenhouse gas emissions from Indian rice fields: Calibration and upscaling using the DNDC model. Biogeosciences 1: 1-11.

16. Hobbs RP, Sayre K, Gupta R (2008) The role of conservation agriculture in sustainable agriculture. Philosophical Transactions of the Royal Society 363(1491): 543-555.

17. (2012) Pathak H, Aggarwal PK (Eds.), Low carbon technologies for agriculture: A study on rice and wheat systems in the Indo-Gangetic Plains. Indian Agricultural Research Institute, India, p. 17.

18. Bhattacharyya P, Sinhababu DP, Roy KS, Dash PK, Sahu PK, et al. (2013) Effect of fish species on methane and nitrous oxide emission in relation to soil $\mathrm{C}, \mathrm{N}$ pools and enzymatic activities in rainfed shallow low land rice fish farming system. Agriculture Ecosystems and Environment 176: 53-62.

19. Bhattacharyya P, Roy KS, Sarkar RK, Neogi S, Dash PK, et al. (2013) Impact of elevated $\mathrm{CO}_{2}$ and temperature on soil $\mathrm{C}$ and $\mathrm{N}$ dynamics in relation to $\mathrm{CH}_{4}$ and $\mathrm{N}_{2} \mathrm{O}$ emissions from tropical flooded rice (Oryza sativa L.). Science of the Total Environment 461-462: 601-611.

20. Yao Z, Zheng X, Xie B, Liu C, Mei B, et al. (2009) Comparison of manual and automated chambers for field measurements of $\mathrm{N}_{2} \mathrm{O}, \mathrm{CH}_{4} \mathrm{CO}_{2}$ fluxes from cultivated land. Atmospheric Environment 43(11): 1888-1896.

21. Pathak H, Upadhyay RC, Muralidhar M, Bhattacharyya $P$ and Venkateswarlu B (Eds.) (2013) Measurement of Greenhouse Gas Emission from Crop, Livestock and Aquaculture. Indian Agricultural Research Institute, New Delhi pp 101.

22. Mukherjee R, Sarkar U (2008) Development of a micrometeorological model for the estimation of methane flux from paddy fields: Validation with standard direct measurements. Environmental Modelling and Software 23(10-11): 1229-1239.

23. Mukherjee R, Barua A, Sarkar U, De BK, Mandal AK (2009) Role of Alternative Electron Acceptors (AEA) to control methane flux from waterlogged paddy fields: Case studies in the southern part of West Bengal India. International Journal of Greenhouse Gas Control 3(5): 664-672.

24. Bhattacharyya P, Neogi S, Roy KS, Rao KS (2013) Gross primary production ecosystem respiration and net ecosystem exchange in Asian rice paddy: An eddy covariance based approach. Current Science 104(1): 67-75. 
25. NOAA-ESRL (2016) National oceanic and atmospheric administration Earth System Research Laboratory, USA.

26. (2007) IPCC [Intergovernmental Panel on Climate Change]. Agriculture. In: Metz B, Davidson OR, Bosch PR (Eds.), Climate Change 2007: Mitigation. Contribution of Working Group III to the Fourth Assessment Report of the Intergovernmental Panel on Climate Change. Cambridge University Press Cambridge United Kingdom.

27. CDIAC (2016) Carbon dioxide information analysis center.

28. Rastogi M, Singh S, Pathak H (2002) Emission of carbon dioxide from soil. Current Science 82(5): 510-517.

29. Alberto MCR, Wassmann R, Hirano T, Miyata A, Kumar A, et al. (2009) $\mathrm{CO}_{2}$ /heat fluxes in rice fields: Comparative assessment of flooded and non-flooded fields in the Philippines. Agricultural and Forest Meteorology 149(10): 1737-1750.

30. Alberto MCR, Hirano T, Miyata A, Wassmann R, Kumar A, et al. (2012) Influence of climate variability on seasonal and interannual variations of ecosystem $\mathrm{CO}_{2}$ exchange in flooded and non-flooded rice fields in the Philippines. Field Crops Research 134(12): 80-94.

31. Hossen MS, Baten MA, Khatun R, Khan MB, Mano M, et al. (2007) Establishment of a flux study site in Bangladesh with its preliminary observation result. Asia Flux Newsletter.

32. Miyata A, Leuning R, Denmead OW, Kim J, Harazano Y (2000) Carbon dioxide and methane fluxes from an intermittently flooded paddy field. Agricultural and Forest Meteorology 102(4): 287-303.

33. XiuE R, Qin Xue W, Cheng Li T, JinShui W, KeLin W, et al. (2007) Estimation of soil respiration in a paddy ecosystem in the subtropical region of China. Chinese Science Bulletin 52: 2722-2730.

34. Minami K, Neue HU (1994) Rice paddies a methane source. Climate Change 27: 13-26.

35. Bouwman AF (1990) Exchange of greenhouse gases between terrestrial ecosystems and the atmosphere. In: Bouwman AF (Ed.), Soil and greenhouse effect. John Wiley \& Sons, New York, USA, pp. 61-127.

36. Wassmann R, Neue HU, Lantin RS, Buendia LV, Renneberg H (2000) Characterization of methane emissions from rice fields in Asia. I. Comparison among fields sites in five countries. Nutrient Cycling in Agroecosystems 58: 1-12.

37. Oo AZ, Win KT, Kimura BSD (2015) Within field spatial variation in methane emissions from lowland rice in Myanmar. Springer Plus 4: 145.

38. Sinha SK (1995) Global methane emission from rice paddies: Excellent methodology but poor extrapolation. Current Science 68(6): 643-646.

39. Wassmann R, Neue HU, Lantin RS, Buendia LV, Renneberg H (2000) Characterization of methane emissions from rice fields in Asia. I. Comparison among fields sites in five countries. Nutrient Cycling in Agroecosystems 58: 13-22.

40. Wang ZY, Xu YC, Li Z, Guo YX, Wassmann R, et al. (2000) A four-year record of methane emissions from irrigated rice fields in the Beijing region of China. Nutrient Cycling in Agroecosystems 58: 55-63.

41. Parashar DC, Mitra AP, Gupta PK, Rai J, Sharma R.C, et al. (1996) Methane budget from paddy fields in India. Chemosphere 33(4): 737-757.

42. Bhatia A, Pathak H, Aggarwal PK (2004) Inventory of methane and nitrous oxide emissions from agriculture soils of India and their global warming potential. Current Science 87(3): 317-324.

43. Alberto MCR, Wassmann R, Buresha RJ, Quiltya JR, Correa TQ et al. (2014) Measuring methane flux from irrigated rice fields by eddy covariance method using open-path gas analyzer. Field Crops Research 160: 12-21.

44. Cai Z, Xing G, Yan X, Xu H, Tsuruta H, et al. (1997) Methane and nitrous oxide emissions from rice paddy fields as affected by nitrogen fertilizers and water management. Plant and Soil 196: 7-14.
45. Kumar U, Jain MC, Pathak H, Kumar S, Majumdar D (2000) Effects of moisture levels and nitrification inhibitors on $\mathrm{N}_{2} \mathrm{O}$ emission from a fertilized alluvial clay loam soil. Current Science 79: 224-228.

46. Davidson EA, Keller M, Erickson HE, Verchot LV, Veldkamp E (2000) Testing a conceptual model of soil emissions of nitrous and nitric oxides. Bioscience 50(8): 667-680.

47. Chao CC, Young CC, Wang YP, Chao WL (2000) Daily and seasonal nitrous oxide fluxes in soils from hardwood forest and different agroecosystems of Taiwan. Chemospher-Global Change Science 2(1): 77-84.

48. Chen J, Xuan J, Du C, Xie J (1997) Effect of potassium nutrition of rice on rhizosphere redox status. Plant and Soil 188: 131-137.

49. Sharma C, Gupta PK, Parashar DC (1995) Nitrous oxide estimates from paddy fields and forests in India. Indian Journal of Radio Space Physics 24: 311-313.

50. Bronson KF, Neue HU, Singh U, Abao EB Jr (1997) Automated chamber measurements of methane and nitrous oxide flux in a flooded rice soil: I. Residue nitrogen and water management. Soil Science Society of America Journal 61(3): 981-987.

51. Bronson KF, Neue HU, Singh U, Abao EB Jr (1997) Automated chamber measurements of methane and nitrous oxide flux in a flooded rice soil: II. Fallow period emissions. Soil Science Society of America Journal 61: 988-993.

52. Ghosh S, Majumdar D, Jain MC (2003) Methane and nitrous oxide emissions from an irrigated rice of North India. Chemosphere 51(3): 181-195.

53.Zou J, Huang Y, Jiang J, Zheng X, Sass RL (2005) A 3-year field measurement of methane and nitrous oxide emissions from rice paddies in China: Effects of water regime crop residue and fertilizer application. Global Biogeochemical Cycles 19(2): 1-9.

54. Helgason BL, Walley FL, Germida JJ (2010) No-till soil management increases microbial biomass and alters community profiles in soil aggregates. Applied Soil Ecology 46(3): 390-397.

55. Sainju UM, Jabro JD, Stevens WB (2008) Soil carbon dioxide emission and carbon content as affected by irrigation tillage cropping system and nitrogen fertilization. Journal of Environmental Quality 37: 98-106.

56. Wassmann R, Aulakh MS (2000) The role of rice plants in regulating mechanisms of methane emissions. Biology and Fertility of Soils 31: 2029.

57. Bouman BAM, Humphreys E, Tuong TP, Barker R (2007) Rice and water. Advances in Agronomy 92: 187-237.

58. Wassmann R, Lantin RS, Neue HU, Buendia LV, Corton TM, et al. (2000) Characterization of methane emissions from rice fields in Asia. III. Mitigation options and future research needs. Nutrient Cycling in Agroecosystems 58: 23-36.

59. Xu S, Jaffé PR, Mauzerall DL (2007) A process-based model for methane emission from flooded rice paddy systems. Ecological Modelling 205: 475-491.

60. Smith KA, Conen F (2004) Impacts of land management on fluxes of trace greenhouse gases. Soil Use and Management 20: 255-263.

61. Aulakh MS (2001) Impact of root exudates of different cultivars and plant development stages of rice (Oryza sativa L.) on methane production in a paddy soil. Plant and Soil 230: 77- 86.

62. Gogoi N, Baruah KK, Gogoi B, Gupta PK (2005) Methane emission characteristics and its relation with plant and soil parameters under irrigated rice ecosystem of north-east India. Chemosphere 59(11): $1677-1684$

63. Ko JY, Kang HW (2000) The effects of cultural practices on methane emissions from rice fields. Nutrient Cycling in Agroecosystems 58: 311314. 
64. Corton TM, Bajita JB, Grospe FS, Pamplona RR, Asis CA, et al. (2000) Methane emission from irrigated and intensively managed rice fields in Central Luzon (Philippines). Nutrient Cycling in Agroecosystems 58: 37-53.

65. Pathak H, Prasad S, Bhatia A, Singh S, Kumar S, et al. (2003) Methane emission from rice-wheat cropping system in the Indo-Gangetic plain in relation to irrigation farmyard manure and dicyandiamide application. Agriculture Ecosystems and Environment 97(1-3): 309-316.

66. Knox JW, Matthews RB, Wassmann R (2000) Using a crop/soil simulation model and GIS techniques to assess methane emissions from rice fields in Asia. III databases. Nutrient Cycling in Agroecosystems 58: 179-199.

67. Xu H, Cai ZC, Jia ZJ, Tsuruta H (2000) Effect of land management in winter crop season on $\mathrm{CH}_{4}$ emission during the following flooded and rice-growing period. Nutrient Cycling in Agroecosystems 58(1-3): 327332.

68. Plugge CM, Zhang W, Scholten JCM, Stams AJM (2011) Metabolic flexibility of sulfate-reducing bacteria. Frontiers in Microbiology 2: 1-8.

69. Babu YJ, Nayak DR, Adhya TK (2006) Potassium application reduces methane emission from a flooded field planted to rice. Biology and Fertility of Soils 42: 532-541.

70. Lu Y, Wassmann R, Neue HU, Huang C (2000) Dynamics of dissolved organic carbon and methane emissions in a flooded rice soil. Soil Science Society of America Journal 64(6): 2011-2017.

71. Neue H (1993) Methane emission from rice fields: Wetland rice fields may make a major contribution to global warming. BioScience 43(7): 466-473.

72. Bharati K, Mohanty SR, Singh DP, Rao VR, Adhya TK (2000) Influence of incorporation or dual cropping of Azolla on methane emission from a flooded alluvial soil planted to rice in eastern India. Agriculture Ecosystem and Environment 79(1): 73-83.
73. Monteny GJ, Bannink A, Chadwick D (2006) Greenhouse gas abatement strategies for animal husbandry. Agriculture Ecosystems and Environment 112(2-3): 163-170.

74. Sangeetha M, Jayakumar R, Bharathi C (2009) Nitrous oxide emission from soils-a review. Agricultural Review 30: 94-107.

75. Pires MV, da Cunha DA, de Matos CS, Costa MH (2015) Nitrogen-use efficiency nitrous oxide emissions and cereal production in Brazil: Current trends and forecasts. PLoS ONE 10(8): e0135234.

76. Bhatia A, Pathak H, Jain N, Singh PK, Tomer R (2012) Greenhouse gas mitigation in rice-wheat system with leaf color chart-based urea application. Environmental Monitoring and Assessment 184(5): 30953107.

77. Malla G, Bhatia A, Pathak H, Prasad S, Jain N, et al. (2005) Mitigating nitrous oxide and methane emission from soil in rice-wheat system of the Indo-Gangetic Plain with nitrification and urease inhibitors. Chemosphere 58(2): 141-147.

78. Upadhyay RK, Patra DD, Tewari SK (2011) Natural nitrification inhibitors for higher nitrogen use efficiency crop yield and for curtailing global warming. Journal of Tropical Agriculture 49(1-2): 19-24.

79. Kallenbach CM, Rolston DE, Horwath WR (2010) Cover cropping affects soil $\mathrm{N}_{2} \mathrm{O}$ and $\mathrm{CO}_{2}$ emissions differently depending on type of irrigation. Agriculture Ecosystems and Environment 137(3-4): 251-260.

80. Liu XJ, Mosier AR, Halvorson AD, Zhang FS (2006) The impact of nitrogen placement and tillage on $\mathrm{NO}, \mathrm{N}_{2} \mathrm{O}, \mathrm{CH}_{4}$ and $\mathrm{CO}_{2}$ fluxes from a clay loam soil. Plant and Soil 280: 177-188.

81. Minami K (2005) N cycle $\mathrm{N}$ flow trends in Japan and strategies for reducing $\mathrm{N}_{2} \mathrm{O}$ emission and $\mathrm{NO}_{3}$ - pollution. Pedosphere 15: 164-172.

For possible submissions Click below: 